\title{
Metformin reverses the resistance mechanism of lung adenocarcinoma cells that knocks down the Nrf2 gene
}

\author{
JIACUI ZHANG ${ }^{1,2^{*}}$, KEPING JIAO ${ }^{2 *}$, JING LIU $^{3}$ and YU XIA ${ }^{1}$ \\ ${ }^{1}$ Department of Internal Medicine, The First Hospital of Lanzhou University; ${ }^{2}$ Department of Respiratory Medicine and \\ ${ }^{3}$ Department of Endocrine Medicine, People's Hospital of Gansu Province, Lanzhou, Gansu 730000, P.R. China
}

Received April 4, 2017; Accepted June 14, 2018

DOI: $10.3892 / 01.2018 .9382$

\begin{abstract}
The nuclear factor, erythroid 2 like 2 (Nrf2)/antioxidant response element (ARE) pathway has an important role in the drug resistance of adenocarcinoma, and may act via different mechanisms, including the mitogen-activated protein kinase (MAPK) pathway. However, it has remained elusive whether metformin affects Nrf2 and regulates Nrf2/ARE in adenocarcinoma. In the present study, reverse-transcription quantitative polymerase chain reaction, cell transfection, western blot analysis, a Cell Counting kit-8 assay and apoptosis detection were used to investigate the above in the A549 cell line and cisplatin-resistant A549 cells (A549/DDP). The results indicated that Nrf2, glutathione S-transferase $\alpha 1$ (GSTA1) and ATP-binding cassette subfamily $\mathrm{C}$ member 1 (ABCC1) were dose-dependently reduced by metformin, and that the effect in A549 cells was greater than that in A549/DDP cells. Treatment with metformin decreased the proliferation and increased the apoptosis of A549 cells to a greater extent than that of A549/DDP cells, and the effect was dose-dependent. After transfection of A549/DDP cells with Nrf2 short hairpin RNA (shRNA), GSTA1 and ABCC1 were markedly decreased, compared with the shRNA-control group of A549/DDP, and low dose-metformin reduced the proliferation and increased apoptosis of A549/DDP cells. Metformin inhibited the Akt and extracellular signal-regulated kinase (ERK)1/2 pathways in A549 cells and activated the p38 MAPK and c-Jun N-terminal kinase (JNK) pathways. Furthermore, in the presence of metformin, inhibitors of the p38 MAPK and JNK signaling pathway at different concentrations did not affect the levels of Nrf2, but inhibitors of the Akt and
\end{abstract}

Correspondence to: Dr Jing Liu, Department of Endocrine Medicine, People's Hospital of Gansu Province, 204 Donggang West Road, Lanzhou, Gansu 730000, P.R. China

E-mail: ransongayst@126.com

*Contributed equally

Key words: lung adenocarcinoma, metformin, cancer, cisplatin, mitogen-activated protein kinase
ERK1/2 pathway at different doses reduced the expression of Nrf2. In addition, inhibitors of p38 MAPK and JNK did not affect the effect of metformin on Nrf2, while inhibitors of Akt and ERK1/2 dose-dependently enhanced the inhibitory effects of metformin in A549 cells. In conclusion, metformin inhibits the phosphoinositide-3 kinase/Akt and ERK1/2 signaling pathways in A549 cells to reduce the expression of Nrf2, GSTA1 and ABCC1. Metformin also reverses the resistance of A549/DDP cells to platinum drugs, inhibits the proliferation and promotes apoptosis of drug-resistant cells. These results may provide a theoretical basis and therapeutic targets for the clinical treatment of tumors.

\section{Introduction}

The major challenge in improving the prognosis of lung adenocarcinoma patients is the drug resistance to cisplatin, in which the Kelch-like ECH-associated protein 1 (Keap1)/nuclear factor, erythroid 2 like 2 (Nrf2)/antioxidant response element (ARE) signaling pathway has a critical role (1-3). With the stimulation of active oxygen, Nrf2 and Keap1 are uncoupled (4). Subsequently, Nrf2 enters the nucleus to form heterologous dimers with Maf to initiate the transcription of ARE target genes (5) and phase II detoxifying enzymes, including superoxide dismutase (SOD), heme oxygenase-1 (HO-1) and glutathione S-transferase alpha 1 (GSTA1) (6). Activation of Nrf2 enhances cellular oxidative stress (7) and the growth of tumor cells (8), thus enhancing the drug resistance of lung adenocarcinoma (9-11). However, treatment with short hairpin RNA (shRNA) targeting Nrf2 may reverse the drug resistance of certain types of cancer cell (12).

Multidrug resistance-associated proteins (MRPs) and phase II detoxification enzymes have synergistic effects (13). Excessive activation of Nrf2 may cause high expression of MRPs, which induces drug resistance in tumor cells (14). Excessive activation of Nrf2 also induces tumor cells to reach a state that is inert to apoptosis and promotes the occurrence of tumors (15). However, after transfection of the CaSki cell line with Nrf2 shRNA, the tumor drug resistance was reversed (16). Nrf2 activation is regulated by the mitogen-activated protein kinase (MAPK) pathway (17), but direct phosphorylation of Nrf2 by MAPKs does not induce Nrf2 activation. Activated $\mathrm{Nrf} 2$ enters the nucleus and forms heterologous dimers with 
phosphorylated extracellular signal-regulated kinase (p-ERK), c-Jun N-terminal kinase (JNK) and p38 MAPK (18). These Nrf2 dimer complexes then activate the transcription of genes downstream of Nrf2 (19), which varies among different organs (20). Nrf2 is known to interact with phosphoinositide-3 kinase (PI3K) (21), and the PI3K/AKT/mammalian target of rapamycin (mTOR) pathway is usually activated in various types of human malignancy, including non-small cell lung cancer $(8,22)$.

Metformin treatment reduces the risk of various tumor types, including ovarian cancer and lung cancer, in diabetic patients $(23,24)$. It blocks different types of tumor cell in the $\mathrm{G} 0 / \mathrm{G} 1$ phase or inhibits the G1/S-phase transition in the cell cycle by regulating the expression of cell cycle proteins and their associated factors (25-27). Metformin also exerts a dose-dependent inhibitory effect on the proliferation of lung cancer cells of various pathological types $(28,29)$. The mechanism may include the activation of the adenosine 5'monophosphate-activated protein kinase (AMPK) pathway $(30,31)$, which reduces the proliferation of tumor cells by inhibiting epidermal growth factor receptor and insulin-like growth factor 1 receptor pathways $(26,32,33)$. Metformin also inhibits the expression of tumor cell apoptosis-associated proteins and prevents the oxidation of tumor cells via an AMPK-independent pathway $(34,35)$. In a study on breast cancer, inhibition of the expression in AMPK by AMPK inhibitors or shRNA abrogated the antineoplastic effect of metformin (36).

To date, only few studies have examined the mechanisms by which metformin inhibits tumor cells. It has been indicated that metformin affects $\mathrm{Nrf} 2$ and regulates the Nrf2/ARE pathway in lung adenocarcinoma cells (37). In the present study, the A549/DDP cisplatin-resistant lung adenocarcinoma cell line was used. To the best of our knowledge, the present study was the first to assess whether metformin affects Nrf2 expression in native A549 and A549/DDP cells, and whether it regulates the Nrf2 and MAPK pathways to affect the expression of ATP-binding cassette subfamily C member 1 (ABCC1) and GSTA1.

\section{Materials and methods}

Reagents. Reverse transcription was performed using the PrimeScript RT reagent kit with gDNA Eraser (cat. no. RR047A) and Real-time polymerase chain reaction (PCR) was performed using the SYBR PrimeScript (Perfect Real Time) kit (cat. no. RR086A; Takara, Dalian, China). MAPK Family bodies Sampler kit (cat. no. 9926), Phospho-MAPK Family Antibody Sampler kit (cat. no. 9910) and Human GAPDH antibody (cat. no. 686613) were obtained from Cell Signaling Technology, Inc. (Danvers, MA, USA), and anti-PCNA antibody (cat. no. ab18197), anti-Nrf2 antibody (cat. no. ab62352), anti-ABCC1 antibody (cat. no. ab24102) and anti-GSTA1 antibody (cat. no. ab111947) were purchased from Abcam (Cambridge, MA, USA). Primary Antibody Dilution Buffer was purchased from Beyotime Institute of Biotechnology (P0023A; Haimen, China). Nrf2-specific shRNA and control shRNA was obtained from Shanghai GenePharma Co., Ltd. (Shanghai, China) (Table I). The Nuclear and cytoplasmic protein Extraction kit was purchased from Beyotime Institute of Biotechnology (P0027). Metformin was obtained from Sangon Biotech Co., Ltd (Shanghai, China). Primer synthesis was performed by Biocolors Biological Technology Co., Ltd. (Shanghai, China). PI3K-specific inhibitor LY294002, ERK-specific inhibitor PD98059, JNK-specific inhibitor SP600125 and p38 kinase-specific inhibitor SB203580 were purchased from BioVision Inc. (Milpitas, CA, USA).

Cell lines and culture. The A549 human lung adenocarcinoma cell line and cisplatin-resistant A549/DDP cells were obtained from GAS Shanghai Life Sciences Cell (Shanghai, China). Cells were cultured in RPMI-1640 dry powder culture medium (Gibco; Thermo Fisher Scientific, Inc., Waltham, MA, USA) with fetal bovine serum (FBS; Hyclone; GE Healthcare, Logan, UT, USA). Cell transfections were performed with Lipofectamine ${ }^{\circledR} 2000$ (Invitrogen; Thermo Fisher Scientific, Inc.) A549 and A549/DDP cells were cultured in RPMI-1640 with $10 \%$ FBS, benzylpenicillin $(100 \mathrm{U} / \mathrm{ml})$ and streptomycin $(100 \mathrm{mg} / \mathrm{ml})$, and cultured at $37^{\circ} \mathrm{C}$ in a humidified atmosphere of air with $5 \% \mathrm{CO}_{2}$.

Nrf2 shRNA transfection. A549/DDP cells were cultured in 24-well cell culture microplates at $1 \times 10^{5}$ cells/well (0.5 ml medium per well, for PCR) or 6-well cell culture microplates at $5 \times 10^{4}$ cells/well $(2 \mathrm{ml}$ medium per well, for western blot) for $24 \mathrm{~h}$. The shRNA transfection was performed with Lipofectamine 2000, according to the manufacturer's protocol. The shRNA/medium mixture was incubated at room temperature for $5 \mathrm{~min}$, then evenly mixed with Lipofectamine 2000 and placed at room temperature for $20 \mathrm{~min}$ for shRNA reagent/Lipofectamine complex formation. The $100-\mu 1$ mixture was then added to the cells. After $12 \mathrm{~h}$, the medium was replaced complete RPMI-1640 medium and the cells were cultured for another $48 \mathrm{~h}$. Cells were then harvested for analysis. To screen for the most effective Nrf2 shRNA, the number of transfected cells was counted under the fluorescence microscope, and The knockdown efficiency was further detected by PCR and western blot analysis, which indicated that $>70 \%$ of the cells were successfully transfected. The shRNA sequences are listed in Table I.

Measurement of gene expression. A549 and A549/DDP cells were cultured in six-well plates at a concentration of $1 \times 10^{5}$ cells/well for $24 \mathrm{~h}$. Total RNA was extracted with TRIzol reagent and reverse transcribed to complementary DNA with the PrimeScript RT reagent kit with gDNA Eraser, according to the manufacturer's protocol. Quantitative PCR was performed using the SYBR Green PCR system on the CFX96 PCR instrument (Bio-Rad Laboratories, Inc., Hercules, CA, USA). The thermocycling conditions were as follows: $1 \mathrm{~min}$ at $95^{\circ} \mathrm{C}$, followed by 40 cycles of $5 \mathrm{sec}$ at $95^{\circ} \mathrm{C}$ and $30 \mathrm{sec}$ at $60^{\circ} \mathrm{C}$. The relative expression of each gene was used to perform relative fold change between treated and control groups using the $2^{-\Delta \Delta \mathrm{Cq}}$ method (38). The primer sequences are listed in Table II.

Western blot analysis. Intracellular protein was extracted with radioimmunoprecipitation assay buffer. The protein 
Table I. shRNA sequences.

\begin{tabular}{lc}
\hline shRNA & \multicolumn{1}{c}{ Sequence } \\
\hline NRF2-shRNA-con & 5'-GGAGGCAAGAUAUAGAUCUTT-3' \\
& 5'-AGAUCUAUAUCUUGCCUCCTT-3' \\
NRF2-shRNA-1 & 5'-CCAGAACACUCAGUGGAA UTT-3' \\
& 5'-AUUCCACUGAGUGUUCUGGTT-3' \\
NRF2-shRNA-2 & 5'-GCCCAUUGAUGUUUCUGAUTT-3' \\
& 5'-AUCAGAAACAUCAAUGGGCTT-3' \\
NRF2-shRNA-3 & 5'-GCACCUUAUAUCUCGAAGUTT-3' \\
& 5'-ACUUCGAGAUAUAAGGUGCTT-3'
\end{tabular}

NRF2, nuclear factor, erythroid 2 like 2; shRNA, short hairpin RNA; con, control.

Table II. Primer sequences.

\begin{tabular}{ll}
\hline mRNA & \multicolumn{1}{c}{ Sequence } \\
\hline NRF2 & 5'-ACACGGTCCACAGCTCATC-3' \\
& 5'-TGTCAATCAAATCCATGTCCTG-3' \\
ABCC1 & 5'-TGTGGGAAAACACATCTTTGA-3' \\
& 5'-CTGTGCGTGACCAAGATCC-3' \\
GSTA1 & 5'-TCCCTCATCTACACCAACTATGAG-3' \\
& 5'-GGTCTTGCCTCCCTGGTT-3' \\
GAPDH & 5'-CCACCCATGGCAAATTCCATGGCA-3' \\
& 5'-TCTACACGGCAGGTCAGGTCCACC-3'
\end{tabular}

ABCC1, ATP-binding cassette subfamily C member 1; GSTA1, glutathione S-transferase alpha 1; Nrf2, nuclear factor, erythroid 2 like 2.

concentration of the cell extract was determined by bicinchoninic acid protein assay, and $25 \mu \mathrm{g}$ loaded sample amounts of total protein were separated by $10 \%$ SDS-PAGE. Proteins were then transferred to a polyvinylidene difluoride membranes (EMD Millipore, Billerica, MA USA), which was blocked in $5 \%$ dry milk for $2 \mathrm{~h}$. Membranes were then probed with the specific primary antibodies: Akt (pan) rabbit mAb (cat. no. 4685; 1:1,000 dilution); phospho-Akt (Ser473) rabbit mAb (cat. no. 4060; 1:1,000 dilution); p44/p42 MAPK(ERK1/2) rabbit mAb (cat. no. 4695; 1:1,000 dilution); phospho-p44/p42 MAPK(ERK1/2) (Thr202/Tyr204) rabbit mAb (cat. no. 4370; 1:1,000 dilution); p38 MAPK Rabbit mAb (cat. no. 8690; 1:1,000 dilution); phospho-p38 MAPK (Thr180/Tyr182) rabbit $\mathrm{mAb}$ (cat. no. 4511; 1:1,000 dilution); SAPK/JNK antibody (cat. no. 9252; 1:1,000 dilution); phospho-SAPK/JNK (Thr183/Tyr185) rabbit mAb (cat. no. 4668, 1:1,000 dilution); The aforementioned antibodies were all obtained by Cell Signaling Technology, Inc.; anti-PCNA antibody (1:1,000 dilution); anti-Nrf2 antibody (1:2,000 dilution); anti-ABCC1 antibody (1:1,000 dilution); anti-GSTA1 antibody (1:2,000 dilution); and GAPDH antibody (cat. no. 686613, 1:1,000 dilution; Cell Signaling Technology, Inc. MA, USA) was used as a loading control at $4^{\circ} \mathrm{C}$ overnight. The membrane was washed three times with Tris-buffered saline containing 1\% Tween-20 (TBST), followed by incubation with peroxidase-labeled secondary antibodies (anti-rabbit IgG; cat. no. 7074; dilution, 1:5,000; Cell Signaling Technology, Inc.) for $2 \mathrm{~h}$ at room temperature. After $24 \mathrm{~h}$ incubation with $5 \mathrm{mM}$ Metformin and the different inhibitors (10-40 $\mu \mathrm{M}$ PI3K-specific inhibitor LY294002; 10-40 $\mu \mathrm{M}$ ERK-specific inhibitor PD98059; 1-20 $\mu \mathrm{M}$ JNK-specific inhibitor SP600125; and 0.1-10 $\mu \mathrm{M}$ p38 kinase-specific inhibitor SB203580), the Nrf2 protein expression was evaluated by western blot analysis. The blots were visualized with the enhanced chemiluminescence plus kit purchased from Engreen Biosystem (Auckland, New Zealand) and the Bio-Rad ChemiDoc MP Gel imaging analysis system (Bio-Rad Laboratories, Inc.), and protein levels were analyzed with ImageJ software v1.8.0 (National Institutes of Health, Bethesda, VA, USA).

Nuclear protein extracts were prepared using the Nuclear and cytoplasmic protein Extraction kit, according to the manufacturer's protocol. The protein concentration of the cell extract was determined by BCA protein assay. A total of $25 \mu \mathrm{g}$ protein were electrophoretically separated and other steps were identical to that aforementioned.

Cell Counting kit 8 (CCK-8) assay. Transfected cells were cultured in 96-well plate at a density of $1 \times 10^{4}$ cells/well with various concentrations of metformin $(0,1,5$ or $10 \mathrm{mM})$ for various durations. Next, $10 \mu \mathrm{l}$ CCK8 was added to each well, followed by incubation for $4 \mathrm{~h}$. The absorbance at the wavelength of $450 \mathrm{~nm}$ was recorded for each well using a Flex Station 3 microplate reader (Molecular Devices, Sunnyvale, CA, USA), and the cell viability was then evaluated according to the manufacturer's protocol.

Apoptosis detection. For apoptosis detection, transfected cells were seeded in a 24 -well plate at $5 \times 10^{4}$ cells $/ \mathrm{ml}$. After treatment with metformin at different concentrations for 24 or $48 \mathrm{~h}$, the cells were collected by trypsin digestion and re-suspended in binding buffer. Cells were incubated with $5 \mu \mathrm{l}$ Annexin V-fluorescein isothiocyanate $(20 \mu \mathrm{g} / \mathrm{ml})$ and $5 \mu \mathrm{l}$ propidium iodide $(5 \mu \mathrm{g} / \mathrm{ml})$ in $100 \mu \mathrm{l}$ volume. Apoptosis was detected using a BD FACS Aria II flow cytometer (BD Biosciences, San Jose, CA, USA).

Statistical analysis. Values are expressed as the mean \pm standard error of the mean. All analyses were performed with SPSS software version 13.0 (SPSS Inc., Chicago, IL, USA). Student's t-test was used for comparison of data between two groups. When multiple groups were compared, one-way analysis of variance followed by the least-significant differences post-hoc test was used for data with a normal distribution, as assessed by the Shapiro-Wilk test. A two-sided $\mathrm{P}<0.05$ was considered to indicate a statistically significant difference.

\section{Results}

Effect of metformin on gene expression in cisplatin-resistant lung adenocarcinoma cells. First, the mRNA and protein expression of GSTA1, ABCC1 and Nrf2 was compared between A459 and A549/DDP cells (Fig. 1). The mRNA 

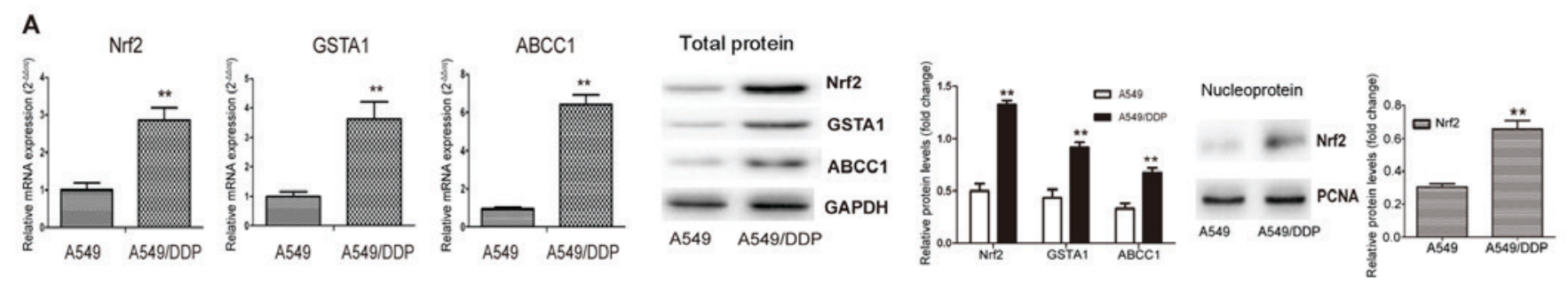

B

A549
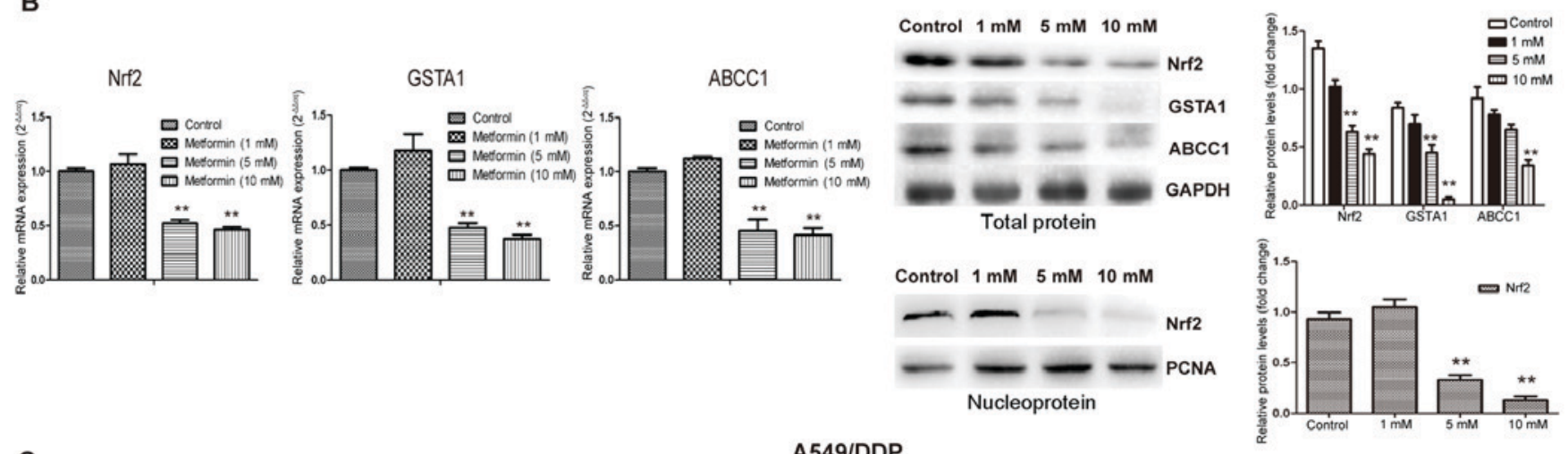

C

A549/DDP
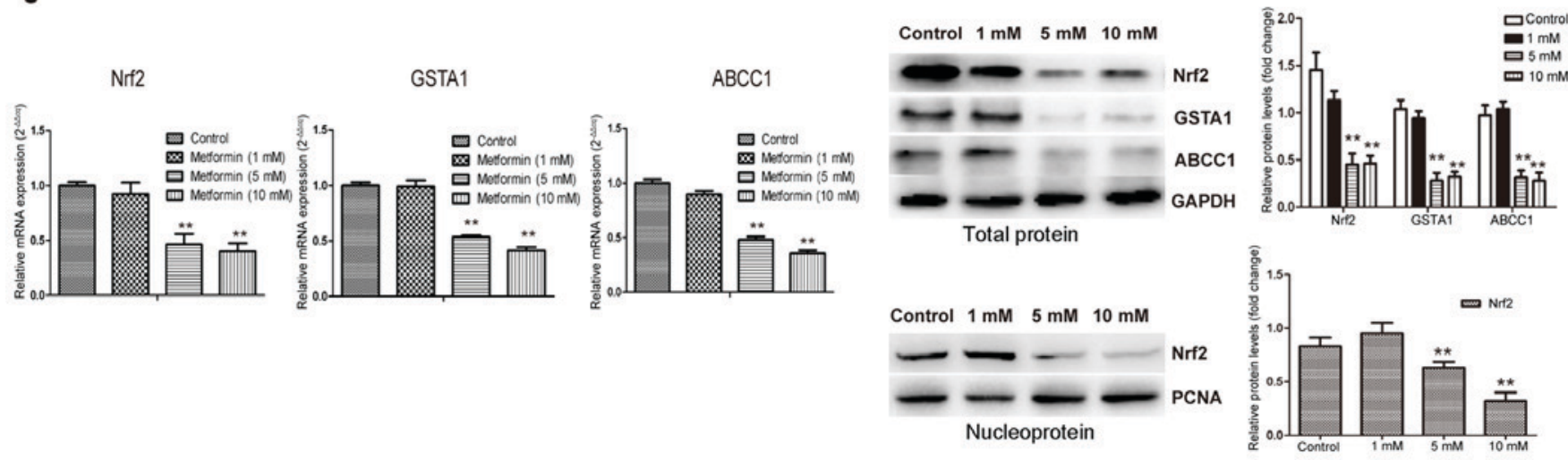

Figure 1. (A) Differential expression of Nrf2, GSTA1 and ABCC1 between A549 and A549/DDP cells. (B and C) Gene and protein levels of Nrf2, GSTA1 and $\mathrm{ABCC} 1$ in A549 and A549/DDP cells after stimulation with different concentrations of metformin. ${ }^{* *} \mathrm{P}<0.01$, compared with control. A549/DDP, cisplatin-resistant A549 lung adenocarcinoma cell line; PCNA, proliferating cell nuclear antigen; Nrf2, nuclear factor, erythroid 2 like 2; GSTA1, glutathione S-transferase $\alpha$ 1.

and protein expression of $\mathrm{Nrf2}, \mathrm{ABCC} 1$ and GSTA1 in A549/DDP cells were significantly higher than those in A549 cells $(\mathrm{P}<0.01)$ (Fig. 1A). Furthermore, the response to different concentrations of metformin $(1,5$ and $10 \mathrm{mM})$ was examined. In A549 and A549/DDP cells, the mRNA and protein expression of Nrf2, GSTA1 and ABCC1 were decreased by metformin in a concentration-dependent manner, with a significant reduction in mRNA expression achieved with metformin concentrations of 5 and $10 \mathrm{mM}$ $(\mathrm{P}<0.01)$ (Fig. 1B).

Effect of metformin on the proliferation and apoptosis of cisplatin-resistant lung adenocarcinoma cells. Cell proliferation and apoptotic rates were then assessed using a CCK-8 assay and flow cytometry, respectively (Fig. 2). A549 cells treated with 5 and $10 \mathrm{mM}$ metformin exhibited decreased proliferation from $24-72 \mathrm{~h}$, and most prominently by $10 \mathrm{mM}$ metformin (Fig. 2A), while A549/DDP cells only displayed a significant decrease in proliferation ability in the presence of $10 \mathrm{mM}$ metformin at $48 \mathrm{~h}(\mathrm{P}<0.01)($ Fig. 2B). The apoptotic rate of A549 treated with 5 and $10 \mathrm{mM}$ metformin was elevated at
$24 \mathrm{~h}$ (Fig. 2C) and further increased at $48 \mathrm{~h}(\mathrm{P}<0.01)$ (Fig. 2E). However, in A549/DDP cells, the apoptotic rate was low at $24 \mathrm{~h}$ and had slightly risen at $48 \mathrm{~h}(\mathrm{P}<0.05)$ (Fig. 2D and F). These results indicate that metformin induced the largest amount of apoptosis in drug-resistant cells at $48 \mathrm{~h}$. Thus, the subsequent experiments were performed using an incubation time of $48 \mathrm{~h}$.

Metformin inhibits cisplatin-resistant lung adenocarcinoma cells via Nrf2. The Nrf2 shRNA sequence no. 2 produced a more pronounced decrease of Nrf2 mRNA and protein expression than the other two shRNAs $(\mathrm{P}<0.01)$ (Fig. 3A); thus, this shRNA was selected for the subsequent experiments. After transfection of A549/DDP cells with Nrf2 shRNA, the gene expression of GST and ABCC1 was decreased (Fig. 3B). It is likely that this downregulation of GSTA1 and ABCC1 may in part influence biological functions including cell proliferation and apoptosis. In A549/DDP cells without transfection, the proliferation was only inhibited by $10 \mathrm{mM}$ metformin; however, the sensitivity of the cells to metformin was enhanced by transfection of Nrf2 shRNA, and a significant 

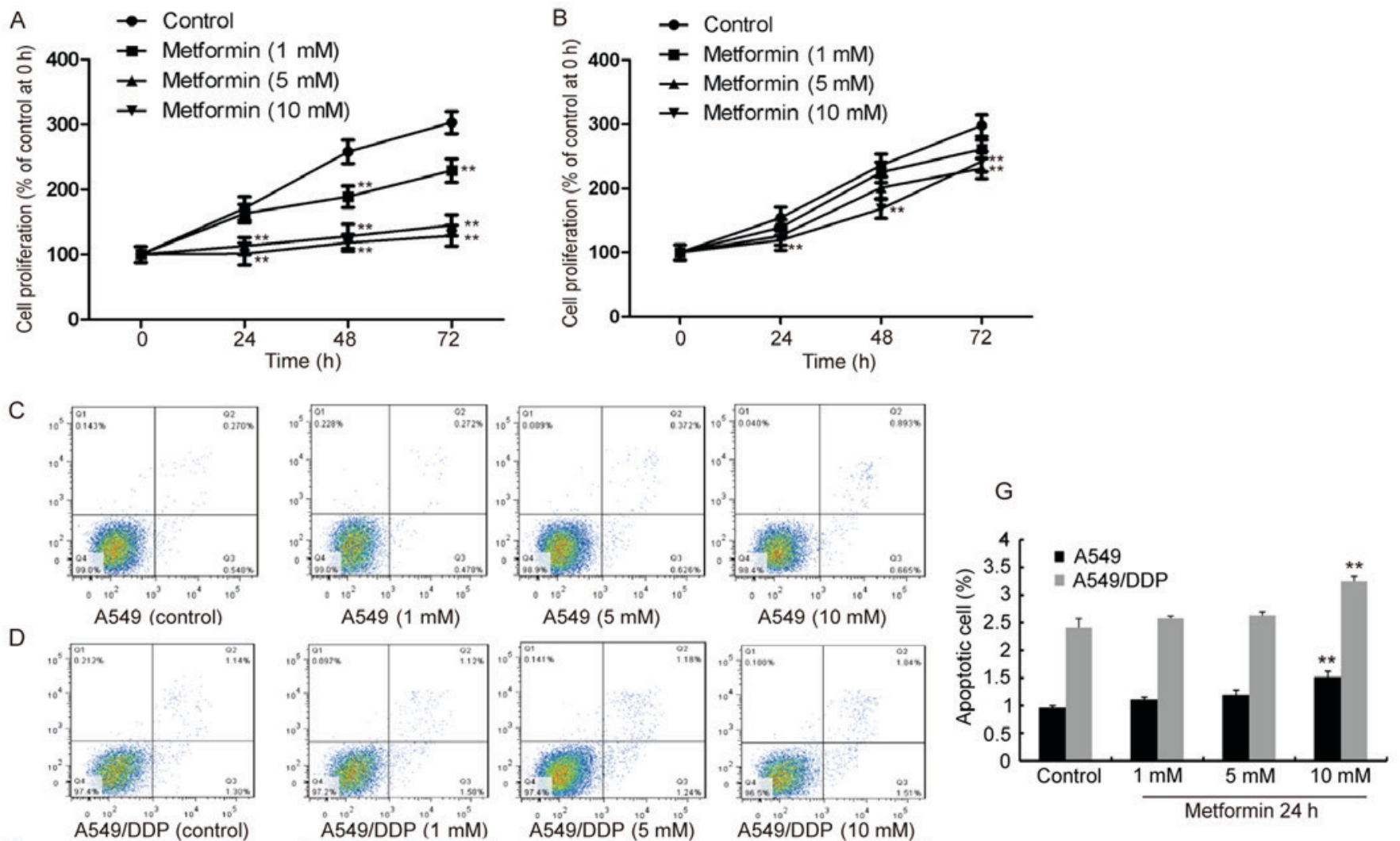

E
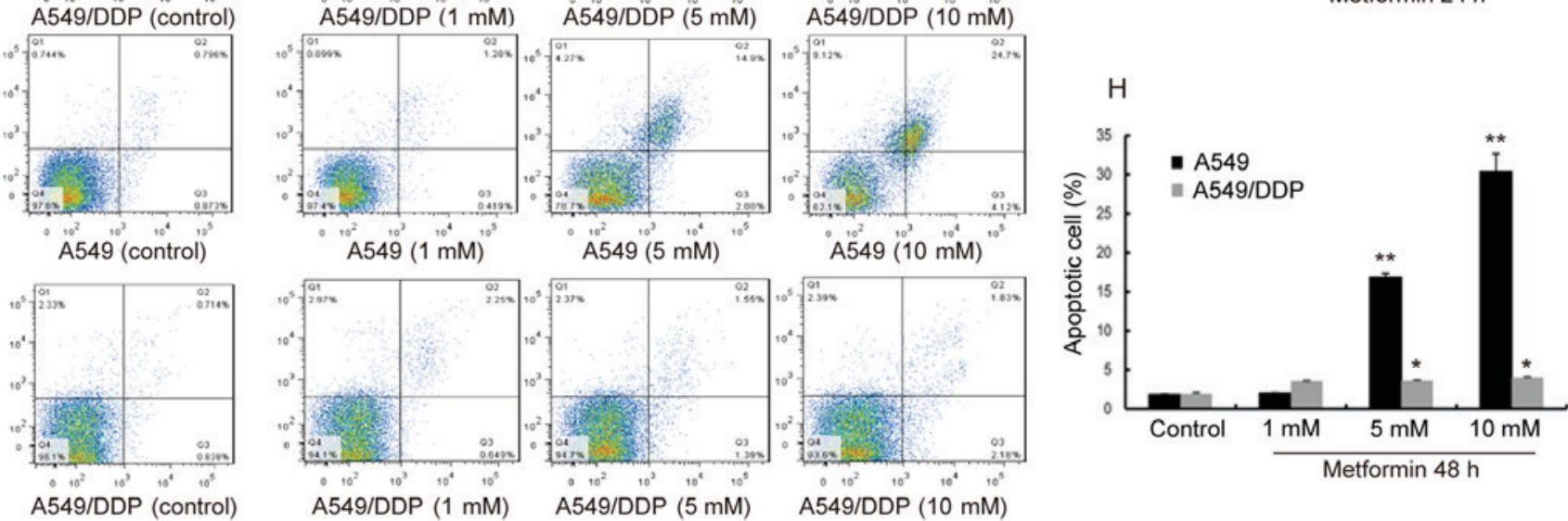

Figure 2. (A) A549 cells treated with 5 or $10 \mathrm{mM}$ metformin exhibited a decreased proliferation, while (B) A549/DDP cells displayed a marked decrease in proliferation ability upon culture with $10 \mathrm{mM}$ metformin for 24-48 h. (C-F) Flow cytometric analysis of A549 and A549/DDP cells treated with 1,5 or 10 mM metformin. The apoptotic rate of A549 cells treated with 5 or $10 \mathrm{mM}$ metformin was (C) increased at $24 \mathrm{~h}$ and (E) highest at $48 \mathrm{~h}$. However, the apoptotic rate of A549/DDP cells (D) remained low at $24 \mathrm{~h}$ and (F) only exhibited a slight increase after $48 \mathrm{~h}$. (G) Data were presented as mean \pm SEM of Figure 2C and D, and each group has three measurements. (H) Data were presented as mean \pm SEM of Figure $2 \mathrm{E}$ and $\mathrm{F}$, and each group has three measurements. Q, quadrant; A549/DDP, cisplatin-resistant A549 lung adenocarcinoma cell line. ${ }^{* *} \mathrm{P}<0.01$ and ${ }^{*} \mathrm{P}<0.05$, compared with control.

reduction in proliferation was achieved by metformin for $48 \mathrm{~h}$ at only $5 \mathrm{mM}$ (Fig. 3C). Additionally, at $72 \mathrm{~h}, 10 \mathrm{mM}$ metformin had a significant inhibition effect, compared with the control $(\mathrm{P}<0.01)$. Furthermore, after transfection with Nrf2 shRNA and culture with metformin for $48 \mathrm{~h}$, the apoptotic rate of A549/DDP cells increased from 4.24 to $27.47 \%(\mathrm{P}<0.01)$ (Fig. $3 \mathrm{C})$. The apoptotic rate was similar to that of A549 cells treated with metformin for $48 \mathrm{~h}$, which indicated that knockdown of Nrf2 sensitized A549/DDP cells to metformin and abrogates their acquired drug resistance.

The PI3K/Akt and ERK1/2 signaling pathways are involved upstream of Nrf2 in the inhibitory effects of metformin on A549 cells. A549/DDP cells are the cells pretreated by cisplatin, which is a interference factor that may activate some downstream signalling pathways to regulate Nrf2. In addition, the results (Fig. 2) identified that the sensitivity of A549/DDP cells to metformin is not as good as that of A549 cells. Therefore the native A549 cell line was selected to study the signaling pathway involved in the process. In A549 cells cultured with 5 and $10 \mathrm{mM}$ metformin, the phosphorylation of Akt and ERK1/2 was decreased, while the phosphorylation of p38 MAPK and phospho-p46 subunit of p-JNK was sharply increased (Fig. 4A) (39). These results indicated that metformin inhibits the Akt and ERK1/2 pathways in A549 and activates the p38 MAPK and JNK pathways. Furthermore, in the presence of metformin, inhibitors of the p38 MAPK and JNK signaling pathway at different concentrations did 
A
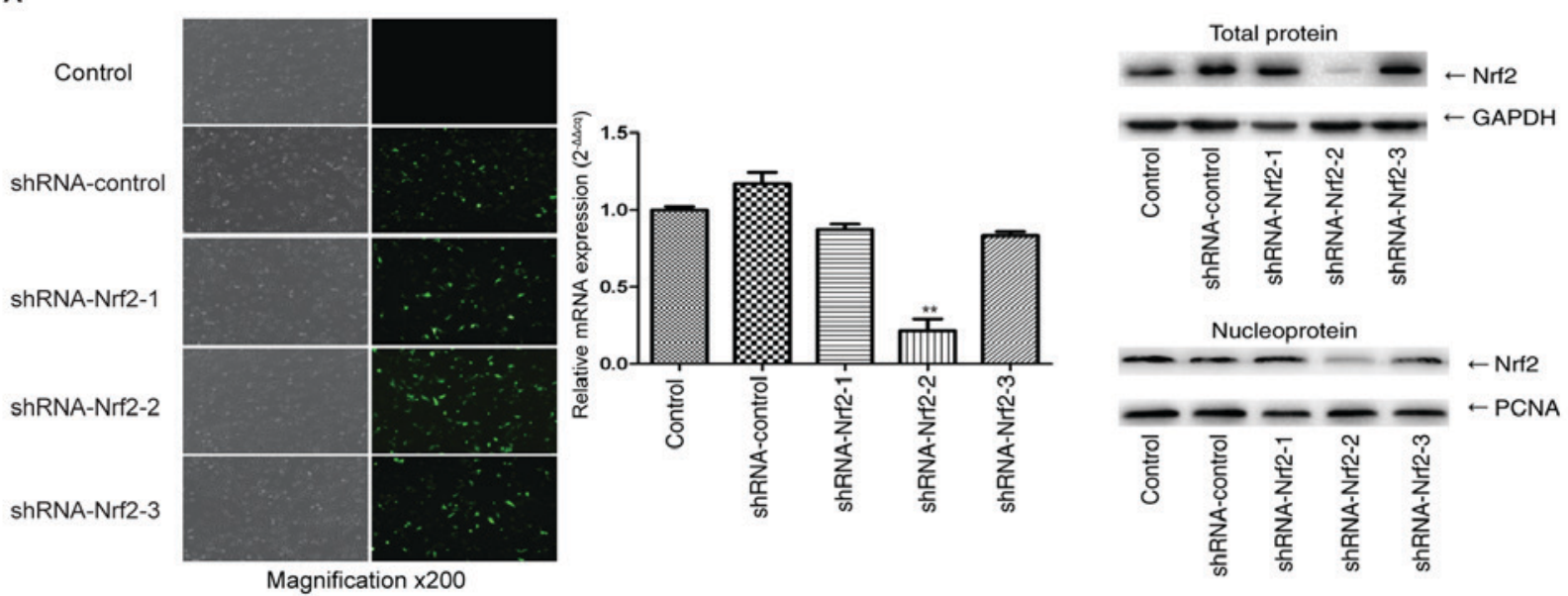

B

A549/DDP
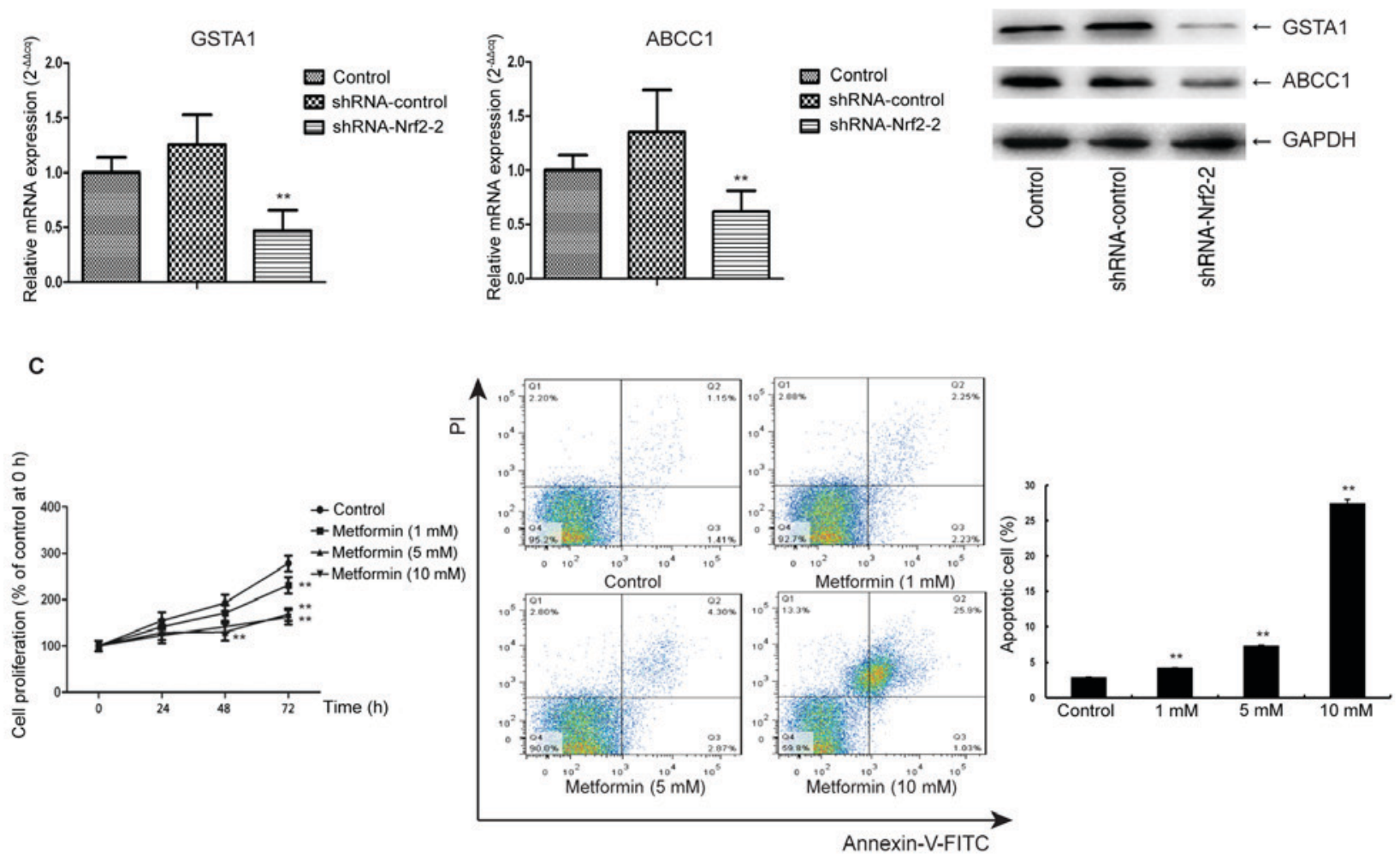

Figure 3. (A) Nrf2 shRNA sequence 2 produced more pronounced decrease of Nrf2 mRNA and protein expression than the other ones (magnification, x200). (B) After Nrf2 knockdown in A549/DDP cells, the mRNA levels of GSTA1 and ABCC1 were decreased. (C) After Nrf2 knockdown, A549/DDP cell proliferation was reduced by metformin at a concentration of $5 \mathrm{mM}$ only. (C) Nrf2 shRNA increased the apoptotic rate of A549/DDP from 4.24 to 27.47\%. A549/DDP, cisplatin-resistant A549 lung adenocarcinoma cell line; PCNA, proliferating cell nuclear antigen; shRNA, short hairpin RNA; Q, quadrant; Nrf2, nuclear factor, erythroid 2 like 2; GSTA1, glutathione S-transferase a 1; ABCC1, ATP-binding cassette subfamily C member $1{ }^{* *} \mathrm{P}<0.01$, compared with control.

not affect the levels of Nrf2 (Fig. 4B). However, inhibitors of the Akt and ERK1/2 pathway reduced the expression of Nrf2 ( $\mathrm{P}<0.01$, Fig. 4B). This suggests that metformin reduces the mRNA and protein expression of Nrf2 by inhibiting the PI3K/Akt and ERK1/2 signaling pathways to affect proliferation and apoptosis.

\section{Discussion}

In the present study, statistically significant differences in the expression of Nrf2, GSTA1 and ABCC1 genes were detected between A549/DDP and A549 cells $(\mathrm{P}<0.01)$. These results were consistent with those of previous studies $(5,11)$. As a possible mechanism, it has been proposed that Nrf2 functions in tumor drug resistance. In a previous study, knockdown of Nrf2 expression by shRNA reversed the drug resistance of tumor cells to tamoxifen (40). Nrf2 increases the expression of Mrp2 by binding to the ARE locus of Mrp2 genes under the stimulation of Nrf2 inducer (41). Previous studies have also indicated that inhibition of Nrf2 is likely to decrease the expression of GSH $(42,43)$. Certain drugs promote Nrf2 nuclear translocation and also stimulate GSH biosynthesis (44), which has an important role in anti-cancer and anti-oxidant activities. Through efflux from the cells, the intracellular concentration of 
A

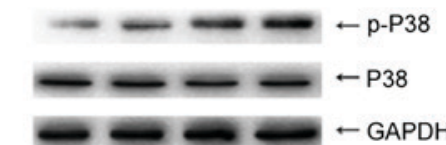

Control $1 \mathrm{mM} 5 \mathrm{mM} 10 \mathrm{mM}$
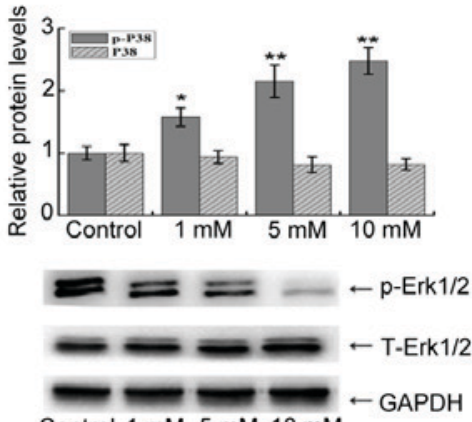

Control $1 \mathrm{mM} 5 \mathrm{mM} 10 \mathrm{mM}$
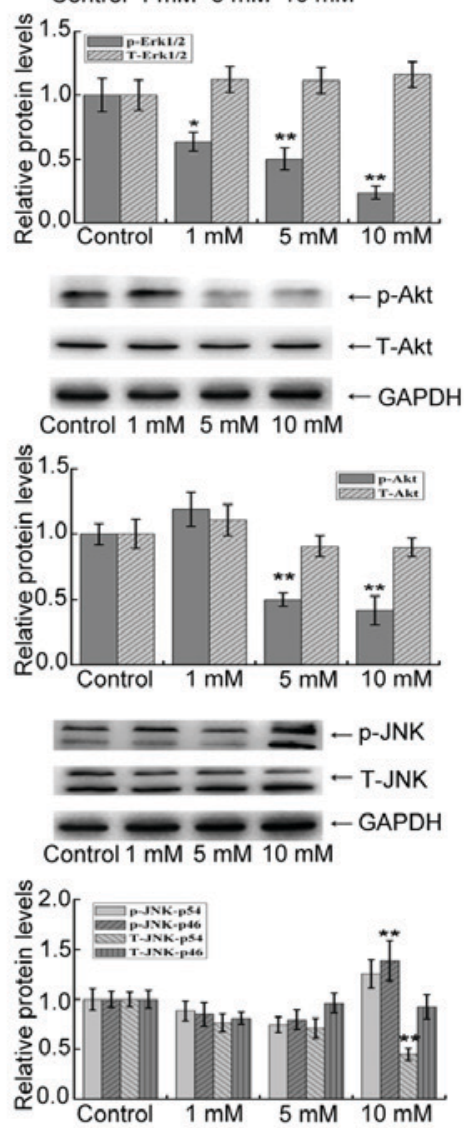

B
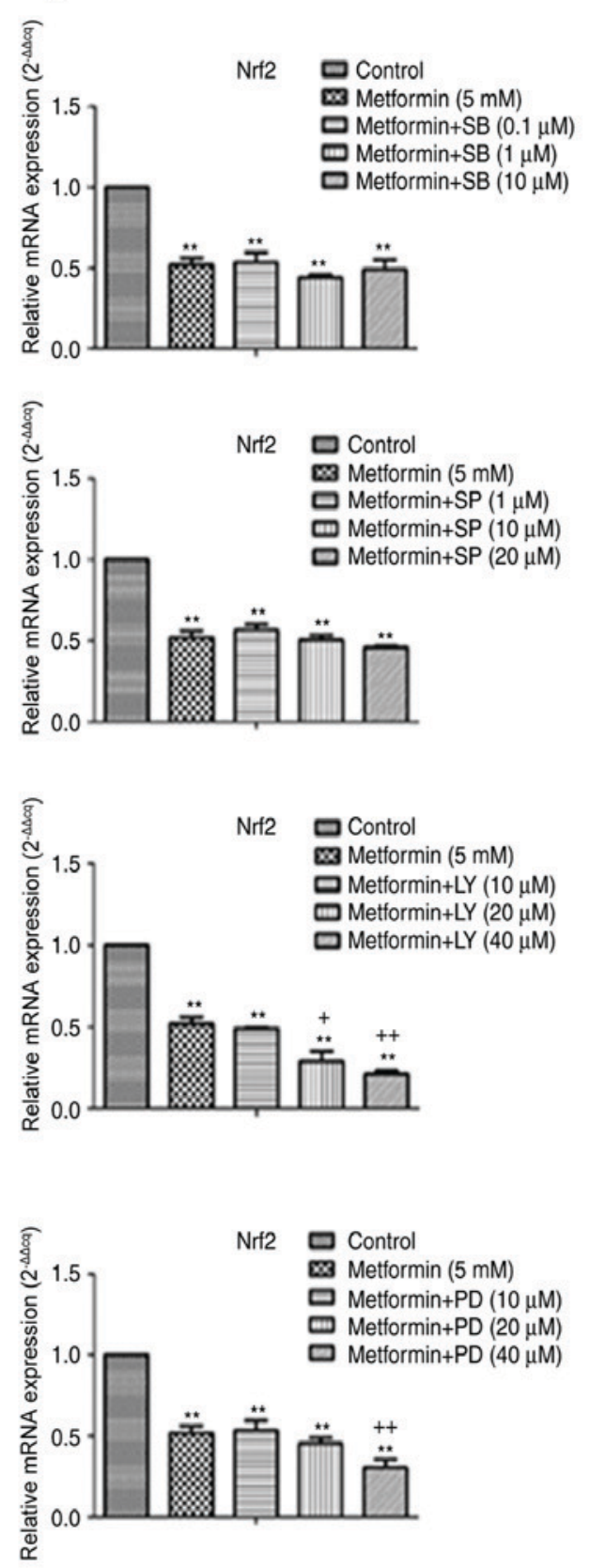

$\longrightarrow-\longrightarrow \mathrm{Nrf2}$

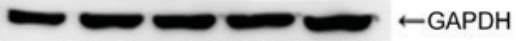

Control $5 \mu \mathrm{M} 0.1 \mu \mathrm{M} 1 \mu \mathrm{M} \quad 10 \mu \mathrm{M}$
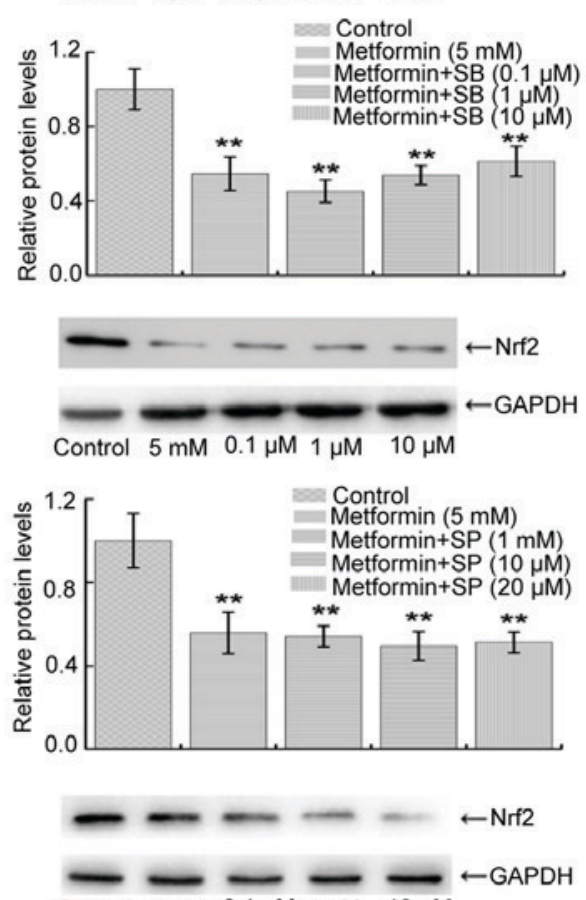

Control $5 \mathrm{mM} \quad 0.1 \mu \mathrm{M} 1 \mu \mathrm{M} \quad 10 \mu \mathrm{M}$
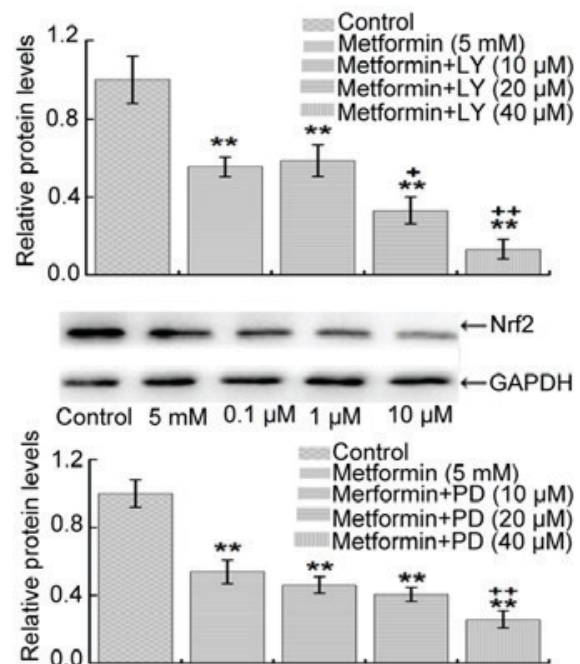

Figure 4. (A) The phosphorylation of Akt and ERK1/2 was decreased, while the phosphorylation of p38 MAPK and JNK was increased after metformin treatment in A549 cells. (B) Treatment with $5 \mathrm{mM}$ metformin and different concentrations of inhibitors of the p38 MAPK and JNK pathway were added, Nrf2 was not affected in the presence of $5 \mathrm{mM}$ metformin. However, when inhibitors of the Akt and ERK1/2 pathway were added, the inhibitory effect of metformin on Nrf2 was further enhanced. ${ }^{* *} \mathrm{P}<0.01$ vs. control; ${ }^{+} \mathrm{P}<0.05$ and ${ }^{++} \mathrm{P}<0.01$ vs. $5 \mathrm{mM}$ metformin group; ${ }^{+} \mathrm{P}<0.05$ vs. 5 mM metformin group. Nrf2, nuclear factor, erythroid 2 like 2; T-JNK, total c-Jun N-terminal kinase; MAPK, mitogen-activated protein kinase; p-ERK, phosphorylated extracellular signal-regulated kinase; LY, phosphoinositide-3 kinase-specific inhibitor LY294002; PD, ERK-specific inhibitor PD98059; SP, JNK-specific inhibitor SP600125; SB, p38 kinase-specific inhibitor SB203580.

anti-cancer drugs is reduced and the combination of intracellular anticancer drugs and target sites is prevented, leading to the drug resistance of tumor cells $(45,46)$. After reduction of the expression of Mrps in human lung adenocarcinoma, the drug resistance to cisplatin was reduced (47). GSH may promote the repair of DNA (45). GSTA1 inhibitors have been reported to enhance the cytotoxicity of cisplatin in drug-resistant cell lines (48). GSTA1 is a phase II conjugated enzyme that detoxifies active electrophilic metabolites. The effects of
GSTA1 depend on the level of GSH, which in turn depends on glutamate cysteine ligase and GSH synthase (49).

Metformin mainly inhibits mitochondrial respiratory chain complex I (50). Inhibition of AMPK expression by shRNA has been reported to reverse the anti-tumor proliferation effect of metformin (51-53). In the present study, metformin inhibited A549 cell proliferation and promoted their apoptosis in a doseand time-dependent manner $(\mathrm{P}<0.01)$. However, in A549/DDP cells, only the highest metformin concentration produced a 
significant effect after $48 \mathrm{~h}(\mathrm{P}<0.05)$. This observation was consistent with those of a previous study (28). After stimulation with metformin, differences in the mRNA and protein expression of GSTA1, ABCC1 and Nrf2 were detected between A549 and A549/DDP ( $\mathrm{P}<0.05)$, particularly the Nrf2 levels of total protein and nuclear protein, were reduced with increasing concentrations of metformin, which was expected and indicated potential tumor inhibition mechanisms of metformin. These results further confirmed the anti-tumor effect of metformin.

The association between MAPKs and Nrf2 may be associated with the presence of MAPK protein phosphorylation sites in the trans-activation domain of Nrf2 (19). A large number of studies reported that MAPKs have an effect on the activity of $\operatorname{Nrf} 2(17,54)$, but there were discrepancies regarding the function of ERK, JNK and p38 in regulating the activity of $\mathrm{Nrf} 2$ between different tumor cell types. The present study revealed that the levels of GSTA1 and ABCC1 were decreased after knockdown of Nrf2. These results suggest that GSTA1 and ABCC1 may be involved in the regulation of $\mathrm{Nrf} 2$ and the biological consequences of Nrf2 perturbation, including proliferation and apoptosis. The changes in growth, apoptosis and gene expression in A549/DDP cells after knockdown of Nrf2 were consistent with those reported in a previous study (16). Therefore, these results suggest that metformin affects the expression of $\mathrm{Nrf} 2$ and its downstream genes via the ERK, JNK and p38 MAPK pathways. Subsequent experiments indicated that treatment with 5 and $10 \mathrm{mM}$ metformin reduced the phosphorylation levels of Akt and ERK1/2, while the phosphorylation levels of p38 MAPK and JNK were increased compared with those in the control group. This confirmed that metformin inhibited the Akt and ERK1/2 pathway and activated the MAPKs p38 and JNK. The PI3K/Akt pathway is involved in the regulation of the proliferation, movement and metabolism of normal cells (55), and mutation and overexpression of these genes frequently occur in cancer (56). The regulatory mechanisms of ERK/MAPK and PI3K/Akt/mTOR pathways are complex, and proteins are currently known to be associated with the PI3K pathway (57), while proteins are known to be associated with MAPK signaling (58). These pathways share interactions between multiple protein nodes, and these interactions are affected by various factors, including cell type, cell differentiation stage and receptor expression levels (59-66). The roles of the PI3K/Akt/mTOR and ERK/MAPK pathways in tumor cell growth, proliferation, differentiation, metastasis and drug resistance are well established (67).

The results of the present study indicated that pharmacological inhibitors of the p38 MAPK and JNK signaling pathways at different concentrations had no impact on Nrf2. However, in response to treatment with Akt and ERK1/2 pathway inhibitors, the level of Nrf2 was reduced. These results suggest that metformin inhibits PI3K/Akt and ERK1/2 to further reduce the expression of Nrf2 gene and protein, thus affecting cell proliferation and apoptosis. These results are consistent with those of previous studies $(34,35)$. Epigenetic regulation of kelch-like $\mathrm{ECH}$ associated protein 1 (Keap1) also affects the response of Nrf2 gene expression to cisplatin $(68,69)$, and Nrf2 then increases the expression of multidrug resistance genes $(70,71)$. Whether Nrf2 is affected by Keap1 in the experiments of the present study will be further explored in a subsequent study.
In conclusion, the present study suggest that metformin reduces the expression of $\mathrm{Nrf} 2$ and its downstream resistance genes GSTA1 and ABCC1 by inhibiting PI3K/Akt and ERK1/2 signaling. Knockdown of Nrf2 abrogated the acquired drug resistance of A549/DDP cells and sensitized them to metformin to a similar level to that of native A549 cells These results may provide a theoretical basis and therapeutic targets for the clinical treatment of tumors. The signaling pathways of MAPK/AKT/ERK/JNK may be downstream effects of the primary effects of metformin, and the upstream mechanisms should be assessed in a future study.

\section{Acknowledgements}

No applicable.

\section{Funding}

The present study was supported by the Regional Science Foundation Project of the National Natural Science Foundation of China (grant no. 81560093) and the Health Industry Research Plan Project of Gansu Province (grant no. GSWSKY-2015-02).

\section{Availability of data and materials}

The analyzed data sets generated during the study are available from the corresponding author on reasonable request.

\section{Authors' contributions}

JZ conducted the experiment and wrote the manuscript. KJ collected the data. JL conceived the paper and revised the manuscript. YX collected and analyzed the data. Furthermore, the final version of the manuscript has been read and approved by all authors.

\section{Ethics approval and consent to participate}

Not applicable.

\section{Patient consent for publication}

Not applicable.

\section{Competing interests}

The authors declare that they have no competing interests.

\section{References}

1. Sporn MB and Liby KT: Nrf2 and cancer: The good, the bad and the importance of context. Nat Rev Cancer 12: 564-571, 2012.

2. Zhao Q, Mao A, Yan J, Sun C, Di C, Zhou X, Li H, Guo R and Zhang H: Downregulation of Nrf2 promotes radiation-induced apoptosis through Nrf2 mediated Notch signaling in non-small cell lung cancer cells. Int J Oncol 48: 765-773, 2016.

3. Chen Z1, Ye X, Tang N, Shen S, Li Z, Niu X, Lu S and Xu L: The histone acetylranseferase hMOF acetylates Nrf 2 and regulates anti-drug responses in human non-small cell lung cancer. Br J Pharmacol 171: 3196-3211, 2014. 
4. Biswas M and Chan JY: Role of Nrf1 in antioxidant response element-mediated gene expression and beyond. Toxicol Appl Pharmacol 244: 16-20, 2010

5. Li SS, Chen ZY, Li J, Xu Z and Yang X: Research progress of Keap1/Nrf2/ARE signaling pathway in central nervous system diseases. Chinese Gen Pract: 3641-3644, 2014.

6. Namani A, Li Y, Wang XJ and Tang X: Modulation of NRF2 signaling pathway by nuclear receptors: Implications for cancer. Biochim Biophys Acta 1843: 1875-1885, 2014.

7. Arnold P, Mojumder D, Detoledo J, Lucius R and Wilms H: Pathophys-iological processes in multiplesclerosis: Focus on nu-clear factor erythroid-2-related factor 2 and emerging pathways. Clin Pharmacol 6: 35-42, 2014

8. Mitsuishi Y, Taguchi K, Kawatani Y, Shibata T, Nukiwa T, Aburatani $\mathrm{H}$, Yamamoto $\mathrm{M}$ and Motohashi H: Nrf2 redirects glucose and glutamine into anabolic pathways in metabolic reprogramming. Cancer Cell 22: 66-79, 2012.

9. Kumar H, Kim IS, More SV, Kim BW and Choi DK: Natural product-derived pharmacological modulators of Nrf2/ARE pathway for chronic diseases. Nat Prod Rep 31: 109-139, 2014

10. Homma S, Ishii Y, Morishima Y, Yamadori T, Matsuno Y, Haraguchi N, Kikuchi N, Satoh H, Sakamoto T, Hizawa N, et al: $\mathrm{Nrf} 2$ enhances cell proliferation and resistance to anticancer drugs in human lung cancer. Clin Cancer Res 15: 3423-3432, 2009.

11. Zhang P, Singh A, Yegnasubramanian S, Esopi D, Kombairaju P, Bodas M, Wu H, Bova SG and Biswal S: Loss of Kelch-like $\mathrm{ECH}$-associated protein 1 function in prostate cancer cells causes chemoresistance and radioresistance and promotes tumor growth. Mol Cancer Ther 9: 336-346, 2010.

12. Yang X, Wang D, Ma Y, Xu X, Zhu Z, Wang X, Deng H, Li C, Chen M, Tong J, et al: Continuous activation of Nrf2 and its target antioxidant enzymes leads to arsenite-induced malignant transformation of human bronchial epithelial cells. Toxicol Appl Pharmacol 289: 231-239, 2015.

13. Lubelska K, Milczarek M, Modzelewska K, Krzysztoń-Russjan J, Fronczyk K and Wiktorska K: Interactions between drugs and sulforaphane modulate the drug metabolism enzymatic system. Pharmacol Rep 64: 1243-1252, 2012.

14. Ji L, Li H, Gao P, Shang G, Zhang DD, Zhang N and Jiang T: Nrf2 pathway regulates multidrug-resistance-associated protein 1 in small cell lung cancer. PLoS One 8: e63404, 2013.

15. Son YO, Pratheeshkumar P, Roy RV, Hitron JA, Wang L, Zhang Z and Shi X: Nrf2/p62 signaling in apoptosis resistance and its Role in cadmium-induced carcinogenesis. J Biol Chem 289: 28660-28675, 2014.

16. Ma X, Zhang J, Liu S, Huang Y, Chen B and Wang D: Nrf2 knockdown by shRNA inhibits tumor growth and increases efficacy of chemotherapy in cervical cancer. Cancer Chemother Pharmacol 69: 485-494, 2012.

17. Lee D, Bae J, Kim YK, Gil M, Lee JY, Park CS and Lee KJ: Inhibitory effects of berberine on lipopolysaccharide-induced inducible nitric oxide synthase and the high-mobility group box 1 release in macrophages. Biochem Biophys Res Commun 431: 506-511, 2013.

18. Cong ZX, Wang HD, Wang JW, Zhou Y, Pan H, Zhang DD and Zhu L: ERK and PI3K signaling cascades induce Nrf2 activation and regulate cell viability partly through Nrf2 in human glioblastoma cells. Oncol Rep 30: 715-716, 2013.

19. Sun Z, Huang Z and Zhang DD: Phosphorylation of Nrf2 at multiple sites by MAP kinases has a limited contribution in modulating the Nrf2-dependent antioxidant response. PLoS One 4: e6588, 2009

20. Levy S, Jaiswal AK and Forman HJ: The role of c-Jun phosphorylation in EpRE activation of phase II genes. Free Radic Biol Med 47: 1172-1179, 2009

21. Abazeed ME, Adams DJ, Hurov KE, Tamayo P, Creighton CJ, Sonkin D, Giacomelli AO, Du C, Fries DF, Wong KK, et al: Integrative radiogenomic profiling of squamous cell lung cancer. Cancer Res 73: 6289-6298, 2013.

22. Yip PY: Phosphatidylinositol 3-kinase-AKT-mammalian target of rapamycin (PI3K-Akt-mTOR) signaling pathway in non-small cell lung cancer. Transl Lung Cancer Res 4: 165-176. 2015.

23. Romero IL, McCormick A, McEwen KA, Park S, Karrison T, Yamada SD, Pannain S and Lengyel E: Relationship of type II diabetes and metformin use to ovarian cancer progression, survival, and chemosensitivity. Obstet Gynecol 119: 61-67, 2012

24. Lai SW, Liao KF, Chen PC, Tsai PY, Hsieh DP and Chen CC: Antidiabetes drugs correlate with decreased risk of lung cancer: A population-based observation in Taiwan. Clin Lung Cancer 13: 143-148, 2012.
25. Kobayashi M, Kato K, Iwama H, Fujihara S, Nishiyama N, Mimura S, Toyota Y, Nomura T, Nomura K, Tani J, et al: Antitumor effect of metformin in esophageal cancer: In vitro study. Int J Oncol 42: 517-524, 2013

26. Kato K, Gong J, Iwama H, Kitanaka A, Tani J, Miyoshi H, Nomura K, Mimura S, Kobayashi M, Aritomo Y, et al: The antidiabetic drug metformin inhibits gastric cancer cell proliferation in vitro and in vivo. Mol Cancer Ther 11: 549-560, 2012.

27. Colquhoun AJ, Venier NA, Vandersluis AD, Besla R, Sugar LM, Kiss A, Fleshner NE, Pollak M, Klotz LH and Venkateswaran V: Metformin enhances the antiproliferative and apoptotic effect of bicalutamide in prostate cancer. Prostate Cancer Prostatic Dis 15: 346-352, 2012

28. Ashinuma H, Takiguchi Y, Kitazono S, Kitazono-Saitoh M, Kitamura A, Chiba T, Tada Y, Kurosu K, Sakaida E, Sekine I, et al: Antiproliferative action of metformin in human lung cancer cell lines. Oncol Rep 28: 8-14, 2012.

29. Koeck S, Amann A, Huber JM, Gamerith G, Hilbe W and Zwierzina $\mathrm{H}$ : The impact of metformin and salinomycin on transforming growth factor $\beta$-induced epithelial-to-mesenchymal transition in non-small cell lung cancer cell lines. Oncol Lett 11: 2946-2952, 2016.

30. Yue W, Yang CS, DiPaola RS and Tan XL: Repurposing of metformin and aspirin by targeting AMPK-mTOR and inflammation for pancreatic cancer prevention and treatment. Cancer Prev Res (Phila) 7: 388-397, 2014.

31. Ferla R, Haspinger E and Surmacz E: Metformin inhibits leptin-induced growth and migration of glioblastoma cells. Oncol Lett 4: 1077-1081, 2012.

32. Liu B, Fan Z, Edgerton SM, Deng XS, Alimova IN, Lind SE and Thor AD: Metformin induces unique biological and molecular responses in triple negative breast cancer cells. Cell Cycle 8: 2031-2040, 2009

33. Vazquez-Martin A, Oliveras-Ferraros C and Menendez JA: The antidiabetic drug metformin suppresses HER2 (erbB-2) oncoprotein overexpression via inhibition of the mTOR effector p70S6K1 in human breast carcinoma cells. Cell Cycle 8: 88-96, 2009.

34. Hanna RK, Zhou C, Malloy KM, Sun L, Zhong Y, Gehrig PA and Bae-Jump VL: Metformin potentiates the effects of paclitaxel in endometrial cancer cells through inhibition of cell proliferation and modulation of the mTOR pathway. Gynecol Oncol 125: 458-469, 2012

35. Rocha GZ, Dias MM, Ropelle ER, Osório-Costa F, Rossato FA, Vercesi AE, Saad MJ and Carvalheira JB: Metformin amplifies chemotherapy-induced AMPK activation and antitumoral growth. Clin Cancer Res 17: 3993-4005, 2011.

36. Gotlieb WH, Saumet J, Beauchamp MC, Gu J, Lau S, Pollak MN and Bruchim I: In vitro metformin anti-neoplastic activity in epithelial ovarian cancer. Gynecol Oncol 110: 246-250, 2008

37. Yu C, Jiao Y, Xue J, Zhang Q, Yang H, Xing L, Chen G, Wu J, Zhang S, Zhu W and Cao J: Metformin sensitizes non-small cell lung cancer cells to an epigallocatechin-3-gallate (EGCG) treatment by suppressing the Nrf2/HO-1 signaling pathway. Int J Biol Sci 13: 1560-1569, 2017.

38. Livak KJ and Schmittgen TD: Analysis of relative gene expression data using real-time quantitative PCR and the 2(-Delta Delta C(T)) method. Methods 25: 402-408, 2001

39. Rodenak-Kladniew B, Castro A, Stärkel P, De Saeger C, García de Bravo M and Crespo R: Linalool induces cell cycle arrest and apoptosis in HepG2 cells through oxidative stress generation and modulation of Ras/MAPK and Akt/mTOR pathways. Life Sci 199: 48-59, 2018.

40. Kim SK, Yang JW, Kim MR, Roh SH, Kim HG, Lee KY, Jeong HG and Kang KW: Increased expression of Nrf2/ARE-dependent anti-oxidant proteins in tamoxifen-resistant breast cancer cells. Free Radic Biol Med 45: 537-546, 2008.

41. Vollrath V, Wielandt AM, Iruretagoyena M and Chianale J: Role of $\mathrm{NrO}$ in the regulation of the Mrp2 (ABCC2) gene. Biochem J 395: 599-609, 2006.

42. Tang X, Wang H, Fan L, Wu X, Xin A, Ren H and Wang XJ: Luteolin inhibits Nrf2 leading to negative regulation of the Nrf2/ARE pathway and sensitization of human lung carcinoma A549 cells to therapeutic drugs. Free Radic Biol Med 50: 1599-1609, 2011.

43. Hwang YP, Choi JH, Choi JM, Chung YC and Jeong HG: Protective mechanisms of anthocyanins from purple sweet potato against tert-butyl hydroperoxide-induced hepatotoxicity. Food Chem Toxicol 49: 2081-2089. 2011 
44. Soeur J, Eilstein J, Léreaux G, Jones C and Marrot L: Skin resistance to oxidative stress induced by resveratrol: From Nrf2 activation to GSH biosynthesis. Free Radic Biol Med 78: 213-223, 2014

45. Meyer $\mathrm{Zu}$ Schwabedissen HE, Grube M, Heydrich B, Linnemann K, Fusch C, Kroemer HK and Jedlitschky G: Expression, localization, and function of MRP5 (ABCC5) a transporter for cyclic nucleotides, in human placenta and cultured human trophoblasts: Effects of gestational age and cellular differentiation. Am J Pathol 166: 39-48, 2005.

46. Lu BC, Li J, Yu WF, Zhang GZ, Wang HM and Ma HM: Elevated expression of $\mathrm{Nrf} 2$ mediates multidrug resistance in $\mathrm{CD} 133^{+}$head and neck squamous cell carcinoma stem cells. Oncol Lett 12 : 4333-4338, 2016.

47. Wang J, Liu X and Jiang W: Co-transfection of MRP and bcl-2 antisense $\mathrm{S}$-oligodeoxynucleotides reduces drug resistance in cisplatin-resistant lung cancer cells. Chin Med J (Engl) 113: 957-960, 2000

48. Neubauer H, Stefanova M, Solomayer E, Meisner C, Zwirner M, Wallwiener D and Fehm T: Predicting resistance to platinum-containing chemotherapy with the ATP tumor chemosensitivity assay in primary ovarian cancer. Anticancer Res 28: 949-955, 2008

49. Meijerman I, Beijnen JH and Schellens JH: Combined action and regulation of phase II enzymes and multidrug resistance proteins in multidrug resistance in cancer. Cancer Treat Rev 34: 505-520, 2008.

50. Stein SC, Woods A, Jones NA, Davison MD and Carling D: The regulation of AMP-activated protein kinase by phosphorylation. Biochem J 345: 437-443, 2000.

51. Tsuji K, Kisu I, Banno K, Yanokura M, Ueki A, Masuda K, Kobayashi Y, Yamagami W, Nomura H, Susumu N and Aoki D: Metformin: A possible drug for treatment of endometrial cancer. Open J Obstet Gynecol 2: 1-6, 2012.

52. Kato K, Ogura T, Kishimoto A, Minegishi Y, Nakajima N, Miyazaki M and Esumi H: Critical roles of AMP-activated protein kinase in constitutive tolerance of cancer cells to nutrient deprivation and tumor formation. Oncogene 21: 6082-6090, 2002.

53. Rattan R, Graham RP, Maguire JL, Giri S and Shridhar V: Metformin suppresses ovarian cancer growth and metastasis with enhancement of cisplatin cytotoxicity in vivo. Neoplasia 13: 483-491, 2011.

54. Krall EB, Wang B, Munoz DM, Ilic N, Raghavan S, Niederst MJ, Yu K, Ruddy DA, Aguirre AJ, Kim JW, et al: KEAP1 loss modulates sensitivity to kinase targeted therapy in lung cancer. Elife: 6. pii: e18970, 2017.

55. Engelman JA, Luo J and Cantley LC: The evolution of phosphatidylinositol 3-kinases as regulators of growth and metabolism. Nat Rev Genet 7: 606-619, 2006.

56. Forbes SA, Bindal N, Bamford S, Cole C, Kok CY, Beare D, Jia M, Shepherd R, Leung K, Menzies A, et al: COSMIC: Mining complete cancer genomes in the catalogue of somatic mutations in cancer. Nucleic Acids Res 39 (Database Issue): D945-D950, 2011.

57. Samatar AA and Poulikakos PI: Targeting RAS-ERK signalling in cancer: Promises and challenges. Nat Rev Drug Discov 13: 928-942, 2014

58. Pilot-Storck F, Chopin E, Rual JF, Baudot A, Dobrokhotov P, Robinson-Rechavi M, Brun C, Cusick ME, Hill DE, Schaeffer L, et al: Interactome mapping of the phosphatidylinositol 3-kinase-mammalian target of rapamycin pathway identifies deformed epidermal autoregulatory factor-1 as a new glycogen synthase kinase-3 interactor. Mol Cell Proteomics 9: 1578-1593, 2010.
59. Aksamitiene E, Kiyatkin A and Kholodenko BN: Cross-talk between mitogenic Ras/MAPK and survival PI3K/Akt pathways: A fine balance. Biochem Soc Trans 40: 139-146, 2012.

60. Fruman DA and Rommel C: P13K and cancer: Lessons, challenges and opportunities. Nat Rev Drug Discov 13: 140-156, 2014.

61. Steelman LS, Chappell WH, Abrams SL, Kempf RC, Long J, Laidler P, Mijatovic S, Maksimovic-Ivanic D, Stivala F, Mazzarino MC, et al: Roles of the Raf/MEK/ERK and $\mathrm{PI} 3 \mathrm{~K} / \mathrm{PTEN} / \mathrm{Akt} / \mathrm{mTOR}$ pathways in controlling growth and sensitivity to therapy-implications for cancer and aging. Aging (Albany NY) 3: 192-222, 2011.

62. Liu P, Cheng H, Roberts TM and Zhao JJ: Targeting the phosphoinositide 3-kinase pathway in cancer. Nat Rev Drug Discov 8: 627-644, 2009.

63. Will M, Qin AC, Toy W, Yao Z, Rodrik-Outmezguine V, Schneider C, Huang X, Monian P, Jiang X, de Stanchina E, et al: Rapid induction of apoptosis by PI3K inhibitors is dependent upon their transient inhibition of RAS-ERK signaling. Cancer Discov 4: 334-347, 2014.

64. Chandarlapaty S, Sawai A, Scaltriti M, Rodrik-Outmezguine V, Grbovic-Huezo O, Serra V, Majumder PK, Baselga J and Rosen N: AKT inhibition relieves feedback suppression of receptor tyrosine kinase expression and activity. Cancer Cell 19: 58-71, 2011.

65. McCubrey JA, Steelman LS, Chappell WH, Abrams SL, Franklin RA, Montalto G, Cervello M, Libra M, Candido S, Malaponte G, et al: Ras/Raf/MEK/ERK and PI3K/PTEN/Akt/mTOR cascade inhibitors: How mutations can result in therapy resistance and how to overcome resistance. Oncotarget 3: 1068-1111, 2012.

66. Fritsch R, de Krijger I, Fritsch K, George R, Reason B, Kumar MS, Diefenbacher M, Stamp G and Downward J: RAS and RHO families of GTPases directly regulate distinct phosphoinositide 3-kinase isoforms. Cell 153: 1050-1063, 2013.

67. Zhang HK, Xu TJ, Ju YH and Yu AM: PI3K/AKT and MAPK/ ERK pathways induce cell cycle arrest and apoptosis in A549 cell through the regulation of FOXO1 transcription factor. J China Med Univ: 908-911, 2012

68. Tian Y, Wu K, Liu Q, Han N, Zhang L, Chu Q and Chen Y: Modification of platinum sensitivity by KEAP1/NRF2 signals in non-small cell lung cancer. J Hematol Oncol 9: 83, 2016.

69. Tian Y, Liu Q, He X, Yuan X, Chen Y, Chu Q and Wu K: Emerging roles of Nrf2 signal in non-small cell lung cancer. J Hematol Oncol 9: 14, 2016.

70. Singer E, Judkins J, Salomonis N, Matlaf L, Soteropoulos P, McAllister S and Soroceanu L: Reactive oxygen species-mediated therapeutic response and resistance in glioblastoma. Cell Death Dis 6: e1601, 2015.

71. Del Vecchio CA, Feng Y, Sokol ES, Tillman EJ, Sanduja S, Reinhardt F and Gupta PB: De-differentiation confers multidrug resistance via noncanonical PERK-Nrf2 signaling. PLoS Biol 12: e1001945, 2014. 